\title{
Metamorfismo de fundo oceânico e alto grau em meta-peridotitos ofiolíticos neoproterozóicos, Faixa Brasília Sul, Minas Gerais
}

\author{
Marco Aurélio Piacentini Pinheiro ${ }^{1}$ \& Marcos Tadeu de Freitas Suita ${ }^{2}$
}

\begin{abstract}
Resumo Na região Sul do Estado de Minas Gerais, entre as cidades de São Vicente de Minas, Andrelândia e Liberdade, na borda meridional do Cráton São Francisco, porção sul da Faixa Brasília, de idade neoproterozóica, são identificados vários corpos ultramáficos em meio a metassedimentos oceânicos, turbíditicos e pelágicos a hemipelágicos, metamorfisados em médio a alto grau e posicionados ao longo de falhas de empurrão profundas associadas a granulitos, retroeclogitos e lentes do embasamento. Dentre destes ultramafitos, de origem controversa e possível natureza ofiolítica, destacam-se os ultramafitos do Morro do Corisco e da Fazenda da Roseta, na região de Liberdade. Estes corpos correspondem a meta-harzburgito cumulático serpentinizado, que apresenta texturas de serpentinização primária (fundo oceânico?) Diagramas litogeoquímicos, discriminantes de ambientes tectônicos, posicionam estes meta-peridotitos em campos específicos de peridotitos ofiolíticos, orogênicos ou abissais. Os dados das análises de elementos menores e traços, quando comparados a valores do manto primitivo, apresentam um enriquecimento em elementos litófilos, e valores próximos aos do manto para os elementos siderófilos, similar a rochas ultramáficas de origem oceânica, submetidas a processos de serpentinização e/ou metamorfismo regional.. Os registros petrológico-estruturais evidenciaram uma evolução em, essencialmente, 4 episódios metamórfico-deformacionais que são: 1) um episódio inicial relacionado às condições de formação das rochas primárias ultramáficas cumuláticas, em provável ambiente crustal-subcrustal oceânico; 2) processos primários de metamorfismo e/ou hidrotermalismo (fundo oceânico?), atingindo a fácies anfibolito; 3) um metamorfismo progressivo relacionado, possivelmente, a exumação destes corpos, atingindo condições de fácies granulito de alta pressão, provavelmente relacionada aos processos de subducção e obducção, ,4) um retrometamorfismo final que atingiu fácies xisto verde..
\end{abstract}

Palavras-chave: ofiolito, metamorfismo de fundo oceânico, alto grau, meta-peridotito, neoproterozóico, Faixa Brasília Sul.

\begin{abstract}
Seafloor and high grade metamorphism in neoproterozoic ophiolitics meta-peridotites, Southern Brasilia fold belt, Minas Gerais. In the southern region of the Minas Gerais State, Brazil, among São Vicente de Minas, Andrelândia e Liberdade, in the southern border of the São Francisco Craton, southern portion of the neoproterozoic Brasília fold-thrust Belt, there are several ultramafic bodies among oceanic, turbiditic and pelagic to hemipelagic metasediments, with high to medium grade metamorphism, positioned along deep thrust faults associated to granulites, eclogites, retroeclogites and basement slivers. These ultramafic rocks, of controversial and probable ophiolitic origin we denote the ultramafic rocks of Morro do Corisco and Fazenda da Roseta, both in the Liberdade City. These ultramafics correspond to serpentinized cumulatic meta-harzburgite which presents primary serpentinization textures (ocean floor?), Lithogeochemical diagrams, for discrimination of tectonic environments, positioned these meta-peridotites in the specific fields of ophiolitic, orogenic and/or abyssal peridotites. Analytical data for minor and trace elements when compared to primitive mantle values show an enrichment in lithophile elements, and values close to those of the mantle for siderophile elements, similar to those rocks of oceanic origin, submitted to serpentinization process and/ regional metamorphism.Structural and petrologic data show an evolution essentially in 4 episodes which are: 1) an earlier episode related to formational of primary ultramafic cumulatic rocks, in a probable crustal-subcrustal oceanic environment 2) primary process of ocean floor metamorphism and/or hydrothermalism which reach amphibolite facies (ocean floor spreading process?); 3) a progressive metamorphism related probably to exumation of these bodies, which reaches granulite facies conditions and it is probably related to early subduction and later obduction processat last, 4) a final retrometamorphism which reached greenschist facies.
\end{abstract}

Keywords: ophiolite, Seafloor metamorphism, high grade, meta-peridotito, neopreoterozoic, Southern Brasília fold belt.

1 - Programa de pós-graduação em "Evolução Crustal e Recursos Naturais”, Departamento de Geologia, Escola de Minas, UFOP, Ouro Preto (MG), Brasil. E-mail: marcoaureliopp@yahoo.com.br

2 - Departamento de Geologia, Escola de Minas, UFOP, Ouro Preto (MG), Brasil. E-mail: suita@degeo.ufop.br 
INTRODUÇÃO O processo de serpentinização em peridotitos está diretamente associado a processos de hidratação, que transformam a mineralogia original anidra em uma série de minerais hidratados (e.g., serpentinas, brucita, talco clorita e anfibólio), através da introdução de água, na forma de hidroxilas $(\mathrm{OH}-)$, nas rochas ultramáficas, e que pode ocorrer em ambientes crustais, oceânicos ou continentais. Independente do ambiente de posicionamento do processo de serpentinização é fundamental a análise das condições de ocorrência desse processo por meio de suas características petrográficas, as quais representam a inter-relação das influências exercidas pela mineralogia, seu arranjo mineralógico, temperatura(s), tipo de deformação, pressão(ões), e por variáveis que normalmente possuem menor importância (e.g., $f_{\mathrm{O}_{2}}, \mathrm{CO}_{2}, f \mathrm{~S}_{2}$; Strieder 1992). Porém, diferenças composicionais entre elementos, isto é, estudos de geoquímica de rochas e de minerais, cuja proporção relativa não foi significativamente modificada pelo processo de serpentinização (comumente pela análise de razões de elementos como $\mathrm{Ti}, \mathrm{Cr}$, Co e Ni, entre os principais), podem fornecer informações significantes sobre a natureza da rocha protólita ou primária e seu ambiente gerador, o que caracteriza as rochas como formadas em ambientes crustais continentais ou oceânicos, seu magma original e sua evolução magmática nos diferentes processos geológicos posteriores e modificadores ao longo de sua história. Assim, o estudo da serpentinização de diferentes corpos ultramáficos pode fornecer importantes subsídios para entender a origem, a história geológica e os processos sofridos por rochas ultramáficas e seu ambiente tectônico de geração e posicionamento.

CONTEXTO GEOLÓGICO REGIONAL E LOCAIS DOS CORPOS Os corpos ultramáficos estudados neste trabalho estão localizados na região entre as cidades de São Vicente de Minas, Arantina e Liberdade (Fig. 1), no sul do Estado de Minas Gerais, porção sul
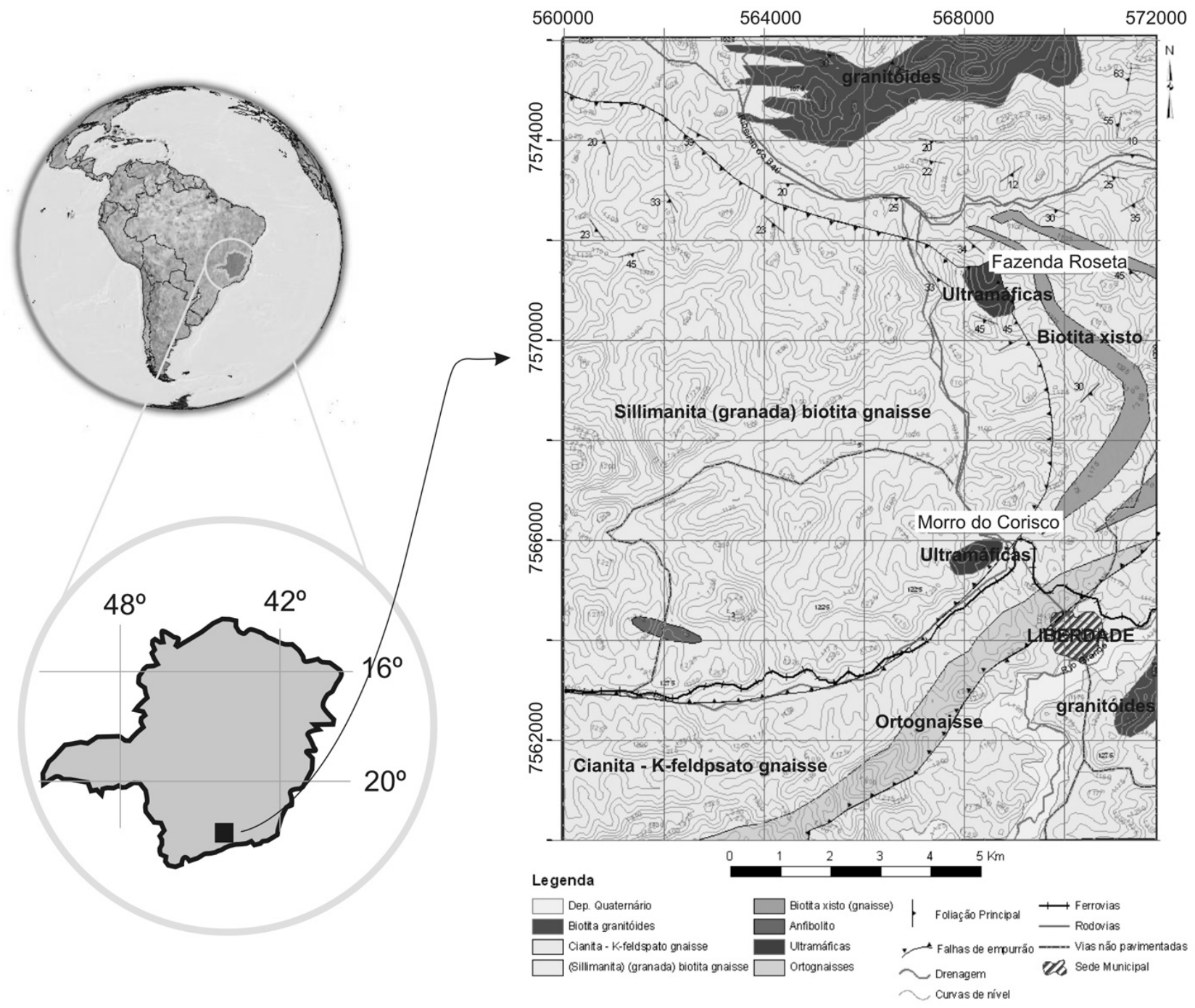

Figura 1 - Contexto geológico geral dos ultramafitos do Morro do Corisco e da Fazenda da Roseta, região da Cidade de Liberdade, no sul de Minas Gerais, em terrenos neoproterozóicos da Faixa Brasília Sul (extraído e modificado de Paciullo 2003). 
do Cráton São Francisco, sul da Faixa neoproterozóica Brasília Sul e posicionam-se em rochas das unidades da Megassequência Andrelândia (Trouw 1986) em diferentes níveis estratigráficos (Almeida 1992 e 1998), inseridas em um domínio alóctone (domínio III; Ribeiro et al. 1990), na base de "uma escama de empurrão que cavalga as rochas do domínio Andrelândia" (Heilbron et al. 2003), a klippe de Carvalhos arquitetada durante a Orogênese Brasiliana (Paciullo et al. 2003) e que sofreu redobramentos da Orogênese Ribeira, posterior, conferindo a esta estrutura a forma de um braqui-sinformal (Heilbron op cit.).

Neste segmento tectônico afloram, essencialmente, dois litotipos supracrustais que são considerados as rochas circundantes e interpretados como metassedimentos turbidíticos, pelágicos a hemipelágicos de fundo oceânico, submetidos a metamorfismo de alto grau (fácies granulito a eclogito de alta pressão). Estes litotipos estão associados a evolução da Faixa Brasília Sul e tiveram posterior re-equilíbrio para fácies de pressão mais baixa, relacionada ao desenvolvimento da Orogênese Ribeira (e.g., Heilbron et al. 2003, Paciullo et al. 2003), os quais são:

1- cianita-feldspato potássico granulito, com proporções variadas de granada e biotita, onde ocorrem bandas mais micáceas (cianita-granada-mica xisto e cianitagranada-biotita gnaisse) e quartzíticas (granada-cianita quartzito) intercaladas a gnaisses leucocráticos; e,

2- granada-clinopiroxênio anfibolito granoblástico, composto essencialmente por plagioclásio, hornblenda, granada, clinopiroxênio e quartzo. Texturas de reequilíbrio para fácies de pressão mais baixa são evidenciadas através de textura coronítica de plagioclásio ao redor de granada, de anfibólio ao redor de clinopiroxênio, simplectitos de plagioclásio e hornblenda entre grãos de granada e clinopiroxênio e exsoluções de minerais opacos em clinopiroxênio. Estas paragêneses de mais alta pressão sofreram um re-equilíbrio para pressão mais baixa, o que é evidenciado pela transformação de cianita em silimanita e de clinopiroxênio em anfibólio.

O corpo do Morro do Corisco (Fig. 1) é o ultramafito mais estudado da região (e.g., Silva 1990, Almeida 1992 e 1998), e apresenta-se predominantemente como serpentinitos maciços com núcleos preservados de (meta)hazburgito, (meta)dunito e (meta) espinélio hornblendito. Os serpentinitos são compostos fundamentalmente por lizardita, minerais opacos e espinélio, com traços de clorita, talco, carbonato, além de ortopiroxênio e olivina reliquiares. Estes serpentinitos possuem bandas de espessuras centi- a decimétricas, de diferentes tonalidades e com pseudomorfos de olivina e/ou ortopiroxênio orientados primariamente, sem correlação com as principais estruturas regionais. Isto sugere-nos a existência de bandamentos composicionais primários e preservados da deformação regional.

Com aproximadamente $4 \mathrm{Km}^{2}$ de ocorrência superficial, o Complexo ultramáfico da Fazenda Roseta (Fig. 1) é o maior corpo ultramáfico da região estudada, e compreende a associação de, ao menos, 5 litotipos: 1. (meta)espinélio harzburgitos; 2. (meta)websteritos; 3. carbonato serpentinito; 4. bronzitito pegmatóide; e, 5 . retro-granulito ultramáfico. Ocorrem, também, clorita e muscovita xistos nas bordas do complexo, que apresentam relações estruturais complexas e de difícil visualização, devido a cobertura vegetal, grau de intemperismo e de tectonismo da região. O carbonato-anfibólio serpentinito, do Complexo da Fazenda da Roseta, objeto de estudo enfatizado neste trabalho, ocorre na região sul-sudeste deste corpo. Este ultramafito ocorre especificamente em afloramentos existentes em trincheiras naturais e em galerias e emboques rasos de exploração mineral. Este litotipo apresenta uma foliação milonítica $\left(\mathrm{S}_{\mathrm{M}}\right)$ de atitude $65 / 60^{\circ}$ a qual tem uma relação de alto ângulo com um provável acamamento ígneo $\left(\mathrm{S}_{0}\right)$, evidenciado por Cr-magnetita e ortopiroxênio estirados e orientados segundo suas maiores dimensões.

CONDIÇÕES DE METAMORFISMO Trouw \& Pankhrust (1993), Ribeiro et al. (1995) e Campos Neto \& Caby (2000), determinaram através de estudos de geobarometria e geotermometria, condições de cerca de 1213,5 Kbares e $800-900{ }^{\circ} \mathrm{C}$ para o equilíbrio de alto grau. No entanto, Perrault \& Martignole (1998 in: Heilbron et al. 2003), determinaram valores de reequilíbrios de 600$700^{\circ} \mathrm{C}$ em par de granada-cordierita. A ocorrência de cordierita, associada com granada e silimanita em leucossomas tardi- $\mathrm{Db}_{2}$ (deformação da Orogênese Brasiliana, na fase 2; Paciullo 2003), em unidades da Megassequência Andrelândia, indica a descompressão do metamorfismo principal (Heilbron et al. 2003). Dados geocronológicos, obtidos pelos sistemas U-Pb, indicam idade de $565 \mathrm{Ma}$ para a descompressão gerada após o pico metamórfico, relacionados a evolução da Faixa Brasília e no intervalo de tempo entre 535 e 502 M.a., para as associações metamórficas relacionadas a estruturação da Faixa Ribeira (Heilbron et al. 2003). Almeida (1998), em estudos destes litotipos (meta)ultramáficos (websteritos, espinélio harzburgitos e serpentinitos), posicionados na base da klippe de Carvalho, obteve valores entre 700 e $900^{\circ} \mathrm{C}$ de temperatura e entre 12 e 13,5 Kbares de pressão, para a formação das associações granulíticas de alta pressão deste domínio tectônico.

\section{ASPECTOS PETROGRÁFICOS \\ Serpentinitos do Morro do Corisco}

ESPINÉLIO SERPENTINITO O espinélio serpentinito apresenta uma matriz de coloração verde musgo a acinzentado, com porções ocre-acastanhadas, destacando-se pseudomorfos de porfiroclastos de ortopiroxênio com textura mesocumulática. Estas fases pré-existentes, junto com o espinélio opaco (Cr-magnetita), ocorrem com orientação incipiente e estão associadas a uma variação mineralógico-textural, refletida em diferenças no tom e na textura da rocha, o que sugere evidências de bandamento composicional primário $\left(\mathrm{S}_{0}\right)$, que é corroborado pela existência de zonas com diferentes composições modais de anfibólio e espinélio. Há, também, no contato entre essas bandas horizontes milimétricos, compostos de espinélio (Cr-magnetita), cominuído e reorientado.

Neste litotipo, observaram-se associações mine- 
rais estáveis, em diferentes campos de estabilidade, as quais foi atribuída a assembléia de olivina + ortopiroxênio + Cr-magnetita, com texturas cumuláticas, como a identidade petro-microtextural ígnea da rocha (Fig. 2A,B,C). Foram determinadas, essencialmente três fases metamórficas para a rocha: 1. serpentinização que forma lizardita e/ou clino-crisólita (Pinheiro 2008; Fig. 2), com uma serpentina (I) associada a uma tremolita (I), texturalmente precoce em relação a uma serpentina mais tardia; 2. metamorfismo progressivo que registra a associação de tremolita (II) + picotita (Fig. 2A e B); e, 3. uma fase de retrometamorfismo que registra o apa- recimento de serpentina (II), clorita e talco+carbonato (Fig. 2C). A diversidade modal existente entre os componentes da rocha, particularmente espinélio e clinoanfibólio, definiu dois litotipos principais: o espinélio serpentinito; e o espinélio-anfibólio serpentinito; os quais, diante da similaridade, serão tratados aqui como espinélio serpentinito.

A serpentina compreende até $75 \%$ da composição modal da rocha, ocorre, primeiramente, na forma de agregados microcristalinos verde-amarelados, levemente pleocróicos e compõe uma típica textura "mesh". Uma segunda gênese deste mineral foi observada atra-

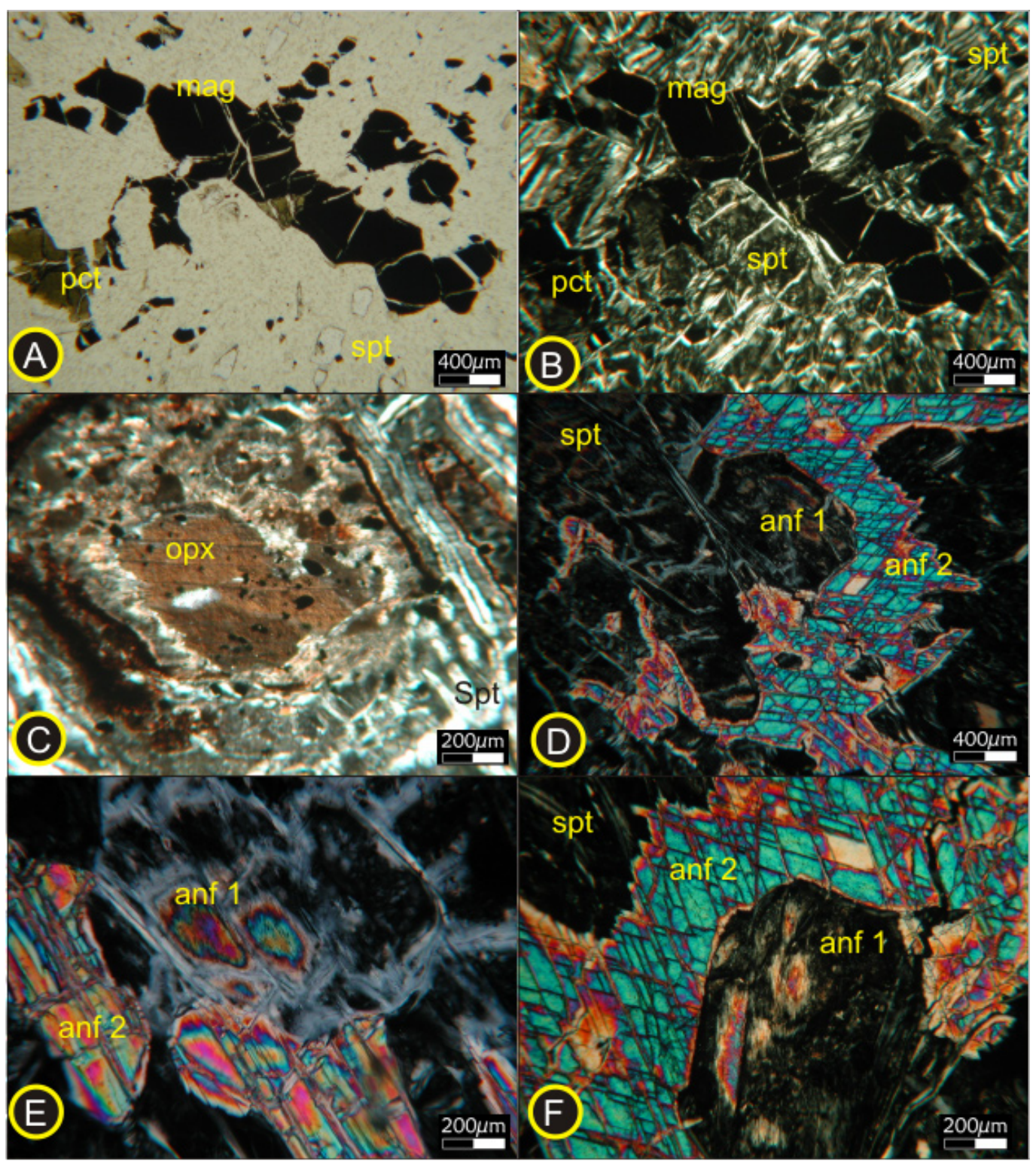

Figura 2 - Fotomicrografias que mostram: A) Cr-magnetita (mag) intercúmulus, parcialmente transformada em picotita (pct) e que envolve pseudomorfos cumuláticos serpentinizados (spt), luz plana; B) mesmo campo anterior sob luz polarizada; C) relicto de ortopiroxênio (opx) cumulático, que está intensamente serpentinizado, luz polarizada; $D$, E e F) clinoanfibólio precoce serpentinizado (anf 1) envolvido por clinoanfibólio tardio (anf 2) intergranular, luz polarizada. 
vés da existência de serpentina, muitas vezes fibrosa, que preenche clivagens de fratura e apresenta textura lepidoblástica. $\mathrm{O}$ ortopiroxênio ocorre como fragmentos reliquiares em núcleos de pseudomorfos, intensamente fraturados, com serpentina, talco e carbonato preenchendo essas zonas, com esses últimos ocupando suas porções mais alteradas e exteriores (Fig. 2C). A Cr-magnetita ocorre de forma inequigranular fina a grossa e hábito granular, perfazendo até $30 \%$ da moda mineralógica. Apresenta texturas do tipo "em atol", de corrosão e esqueletal. Em seções com textura anédrica, esta fase envolve pseudomorfos de olivina e ortopiroxênio, o que sugere um arranjo do tipo intercumulático (Fig. 2 A e B). Picotita (espinélio castanho-esverdeado) e, posteriormente, anfibólio e clorita, substituem a $\mathrm{Cr}$ magnetita. Uma geração tardia de magnetita xenoblástica fina ocorre a partir de talco e serpentina e compõe arranjos do tipo "trilhas" e "nuvens de opacos".

O clinoanfibólio cálcico (tremolita), comumente, ocorre na forma de granoblastos incolores, finos a médios, essencialmente xenoblásticos, apresenta uma birrefringência moderada, com cores de interferência vivas (atingindo o azul de $2^{\circ}$ ordem) e a típica extinção oblíqua $\left(124^{\circ}\right)$. No entanto, foi observada a ocorrência de dois tipos de anfibólios monoclínicos: 1) um tipo localizado nos núcleos de pseudomorfos mesocumuláticos e intensamente serpentinizado (tremolita I; Fig. 2D, E, F); e, 2) e outro como granoblastos (tremolita II), aparentemente gerados às custas de serpentinas e minerais do protólito, que apresentam textura inequigranular, fina a média e que estão geralmente associados ao espinélio opaco e castanho-esverdeado, com padrão de fraturamento similar ao dos pseudomorfos de olivina e ortopiroxênio (Fig. 2D, E e F). Em porções com menor teor de anfibólios (espinélio serpentinito), foi observado uma associação estável entre a tremolita II e a picotita, o que sugere, assim, uma origem paragenética entre essas fases. No entanto, na porção com mais anfibólio (espinélio-anfibólio serpentinito) observou-se a tremolita II, xenoblástica, englobando pseudomorfos serpentinizados com a tremolita I (precoce) preservada no núcleo dessas estruturas, e que ocupa espaços intergranulares ("interpseudomorfos"), semelhante a textura intercúmulática (Fig. 2D, E e F).

A clorita ocorre em lamelas fracamente pleocróicas, em matizes de amarelo pálido, com textura lepidoblástica, fina a média e se forma à custa de espinélio opaco, serpentina e clinoanfibólio e, geralmente, está associada com talco. O talco ocorre em lamelas incolores de alta birrefringência e ocorre de três maneiras principais na rocha: 1) como produto de alteração da serpentina, quando exibe textura lepidoblástica inequigranular fina; 2) associado a massa de carbonatos e argilo-minerais ocre-acastanhados no manto de pseudomorfos e mostra textura decussada em agregados microcristalinos; e, 3) em venulações que cortam a serpentina, com textura lepidoblástica inequigranular grossa, comumente associado a clorita e magnetita tardias. O carbonato ocorre de modo microcristalino associado ao talco, no manto de alteração dos pseudomorfos.

\section{Serpentinito da Fazenda da Roseta}

\section{CARBONATO- ANFIBÓLIO SERPENTINITO Esta}

litologia apresenta uma coloração verde musgo, sendo observados grossos pseudomorfos de ortopiroxênio, opacos e agregados microcristalinos de serpentina, que apresentam porções granulares de coloração ocre onde se destacam fases pré-existentes pseudomorfisadas. Do mesmo modo que nos serpentinitos do Morro do Corisco, foram identificadas 4 assembléias minerais, sendo: 1) uma associada ao provável protólito ígneo e composta da assembléia olivina +ortopiroxênio $+\mathrm{Cr}$-magnetita, que apresenta textura cumulática e composição harzburgítica; 2) a presença de serpentina precoce (I), registro provável de uma atividade hidrotermal primária; 3) uma associação de metamorfismo progressivo, que registra a entrada de clinopiroxênio, e carbonato, + picotita $\leftrightarrow$ Cr-hercinita no sistema (referente ao pico metamórfico); e, por fim, 4) uma associação retro-metamórfica, com a associação de tremolita e clorita.

A serpentina, o mineral mais abundante na rocha, ocorre na forma de agregados microcristalinos amarelados, levemente pleocróicos que compõe textura do tipo mesh e envolve relictos de olivina e ortopiroxênio (Figs. $3,4)$. A serpentina, comumente, está associada a clorita, a qual, muitas vezes, ocorre de forma lepidoblástica, concordante aos planos e descontinuidades onde ocorre a serpentinização. A olivina apresenta-se incolor, com alto relevo e birrefringência, tem cores de interferência vivas, está intensamente fraturada e serpentinizada (Fig. 3 A, B) e o ortopiroxênio aparece de forma semelhante a olivina, porém esta fase, em algumas seções ocorre na forma de cristais idiomórficos finos, em contato reto com carbonato metamórfico (Fig. 3C, D, E, F). O clinopiroxênio ocorre em cristais incolores xenoblásticos, com textura inequigranular, finos a grossos, apresenta uma birrefringência média com cores de interferência moderadas e, freqüentemente, ocupa espaços intergranulares de fases pseudomórficas cumuláticas (Fig. 4), de modo semelhante a ocorrência do anfibólio (II) dos serpentinitos do Morro do Corisco (espinélio-anfibólio serpentinito; Fig. 2).

O carbonato, mineral que atinge até $20 \%$ da composição modal da rocha, forma xenoblastos incolores de baixo relevo e cores de interferência extremas, ocupa espaços intergranulares, semelhantes aos encontrados em rochas mesocumuláticas, de fases pseudomorfisadas, possivelmente, de olivina e ortopiroxênio (Fig. 4). Em muitas seções, observa-se o carbonato consumindo serpentina e clinopiroxênio, havendo em muitas seções inclusões destas fases no carbonato, o qual subsidia a geração de clinoanfibólio (Fig. 4). Uma particularidade observada no carbonato é sua ocorrência em contato reto, o que indica equilíbrio estável com ortopiroxênio reliquiar ígneo (Fig. 3 C, D). Em algumas seções observaram-se finos opacos orientados, compondo arranjos do tipo "trilhas de opacos", sugerindo a herança de uma superfície de cisalhamento pretérita, responsável pela cominuição destes opacos, feição similar aquelas observadas no contato entre os diferentes serpentinitos do Morro do Corisco. 


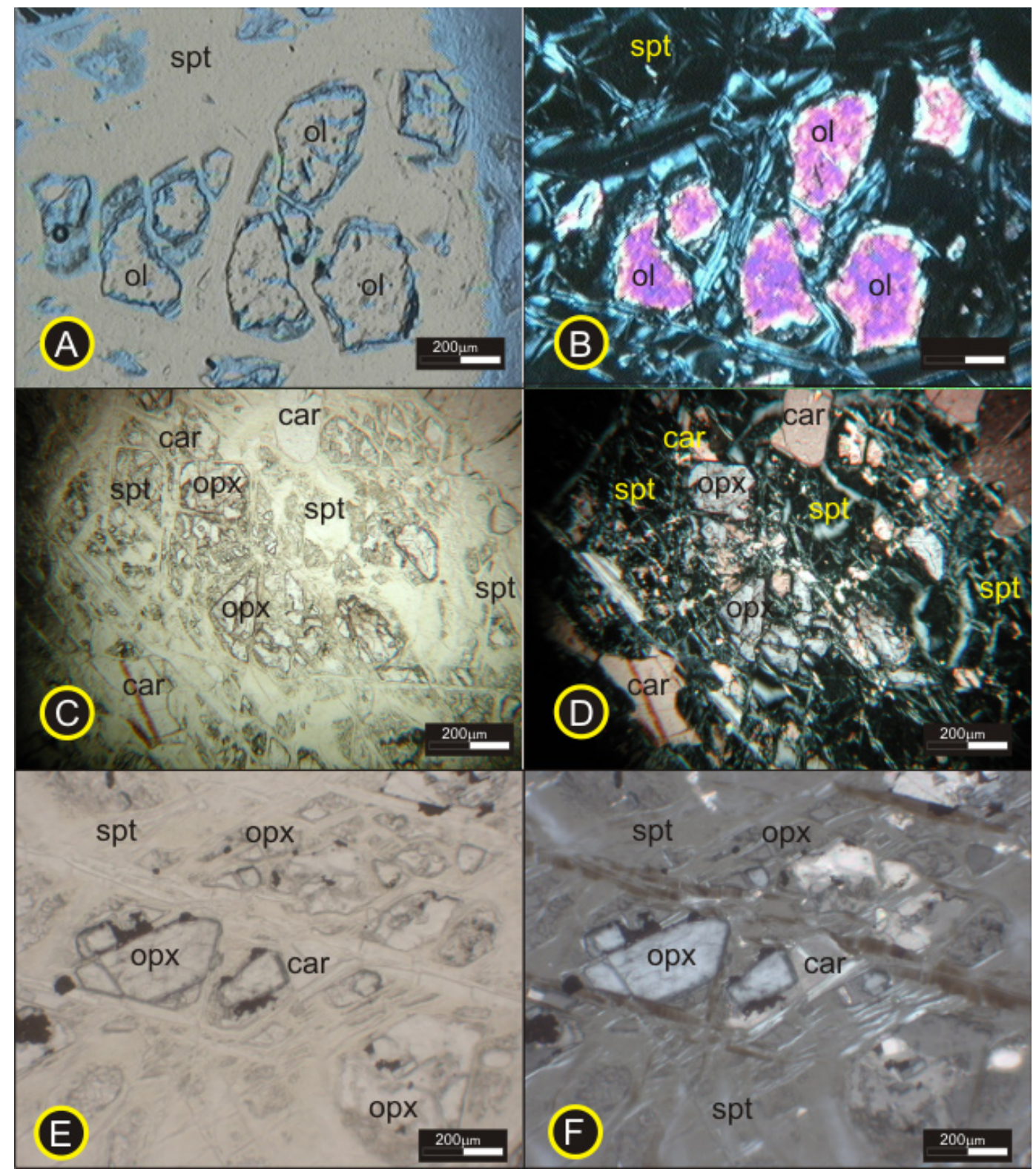

Figura 3 - Fotomicrografias que apresentam: A) cristais de olivina (ol) reliquiar cumulática intensamente serpentinizados (luz paralela); B) mesmo campo anterior, sob luz polarizada; $C$ e E) ortopiroxênio (opx) reliquiar cumulático em condição de equilibrio com carbonato (car) granoblástico, gerado as custas de serpentina (spt), luz paralela; D e F) mesmos campos anteriores, sob luz polarizada.

O clinoanfibólio (tremolita), apresenta-se incolor e ocupa espaços intergranulares entre fases pré-existentes pseudomorfizadas e geradas às custas de clinopiroxênio e carbonato (Fig. 4C, D, E, F). Os minerais opacos ocorrem na forma de cristais xenomórficos, compõe textura inequigranular fina a grossa, comumente com hábito vermiforme, e apresentam texturas de reação do tipo "em atol" e "de corrosão". Estes minerais geralmente ocupam espaços "inter-pseudomórficos" (intergranulares), e encontram-se inclusos nos anfibólios e em carbonato. Geralmente, estas fases estão transformadas em clorita, junto com a serpentina e picotita. A clorita ocorre na forma de finas palhetas incolores e forma-se a custa de opacos, serpentina e anfibólios.

METAMORFISMO As condições da geração de um protólito harzburgítico cumulático, podem ser estipuladas em campos de estabilidade na ordem de 8-20 Kbares, para associações com espinélio +olivina +ortopiroxênio, com granada ou plagioclásio representando a fase aluminosa em campos de estabilidade acima e abaixo desses valores, respectivamente (Fig. 5; O'Hara 1967 e Green \& Ringwood 1970).

De acordo com os dados petrográficos e de paragêneses minerais obtidos nas associações petro-tectônicas estudadas de Morro do Corisco e Fazenda da Ro- 


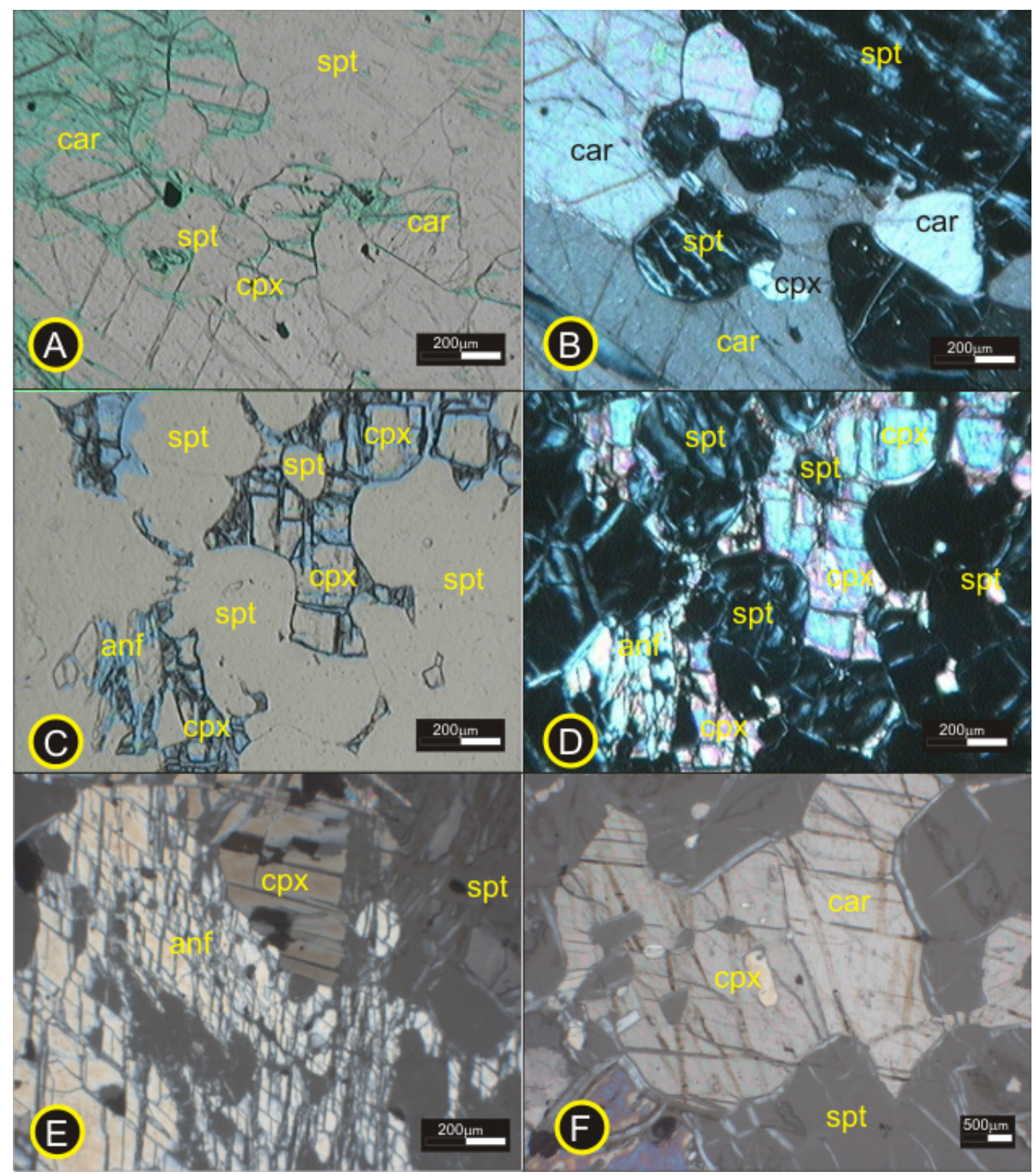

Figura 4 - Fotomicrografia que mostra: A) carbonato granoblástico (car) sendo gerado as custas de serpentina (spt), luz paralela; B) mesmo campo anterior sob luz polarizada; C) clinopiroxênio (cpx) granoblástico intergranular sendo gerado as custas de serpentina (spt) e que subsidia a formação de clinoanfibólio (anf), luz paralela; D) mesmo campo anterior sob luz polarizada; E) clinoanfibólio (anf) sendo gerado as custas de clinopiroxênio (cpx), luz polarizada; F) clinopiroxênio (cpx) granoblástico que subsidia a formação de carbonato granoblástico (car), luz polarizada.

seta, sugere-se que o processo de serpentinização seja primário e, para este processo, um ambiente metamórfico inicial em condições de fácies phrenita-pumpeeleita (condições de soterramento) a anfibolito, com valores de temperaturas entre 250 e $300^{\circ} \mathrm{C}$ e pressões litostáticas entre, 0,1 a 0,6 Gpa. Desta forma, o surgimento precoce de lizardita e/ou crisotila nestas rochas peridotíticas serpentinizadas é sugerido como devido a fluidos oceânicos ou continentais, pré-pico metamórfico (e.g., Evans \& Frost 1975, Evans 1977 e Coleman 1977).

A associação mineralógica do pico metamórfico na área de trabalho, para os serpentinitos do Morro do Corisco, é representada pelo aparecimento de clinopiroxênio, carbonato, tremolita (II) e do espinélio castanho esverdeado (picotita ou Cr-hercinita). Evans \& Frost (1977) consideraram a associação enstatita +olivina +tremolita como sendo típica da fácies anfibolito superior e enstatita +clinopiroxênio (diopsídio) +olivina +espinélio castanho esverdeado como típica da fácies granulito, em associações mineralógicas ultramáficas submetidas a metamorfismo progressivo. No serpentinito da Fazenda Roseta, a blastese de tremolita II, a partir de clinopiroxênio e carbonato, representaria uma etapa de diminuição na temperatura do sistema com concentrações significantes de $\mathrm{CO}_{2}$, em passagem de fácies 


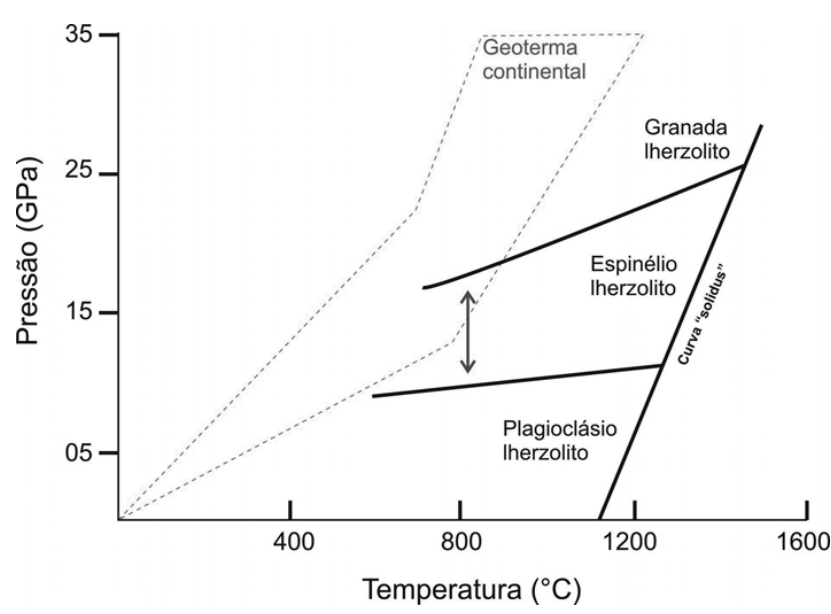

Figura 5 - Condições calculadas de pressão e temperatura do manto para condições de estabilidade de lherzolitos portadores de plagioclásio, espinélio ou granada (extraido e modificado de Winter 2001). A seta vermelha destaca o campo de estabilidade estimado para a geração dos peridotitos com espinélio e meta-serpentinitos do Morro do Corisco e da Fazenda da Roseta.

granulito inferior a anfibolito superior (Fig. 6). Yardley \& Mackenzie (1996) descreveram a ocorrência da associação carbonato +enstatita +olivina como típica de fácies granulito em serpentinitos e peridotitos serpentinizados submetidos a um metamorfismo progressivo.

$\mathrm{O}$ aparecimento de fases tardias como clorita, serpentina tardia, talco e carbonato, nos serpentinitos do Morro do Corisco e nos da Fazenda da Roseta, configura o caráter retrometamórfico (metassomático) ao qual as rochas foram submetidas em eventos posteriores de mais baixo grau, que estão expressos nestas reações típicas de fáceis xistos verdes (Yardley 1996, Winter 2001). A figura 7 apresenta uma trajetória estipulada, considerando as condições de pressão e temperatura estimadas pelas paragêneses metamórficas, para os (meta)serpentinitos do Morro do Corisco e da Fazenda da Roseta. É atribuída a estes meta-serpentinitos uma evolução metamórfica progressiva(até o alto grau) e regressiva (até o grau baixo ou fácies xisto verde) no sistema CMAS-HC $\left(\mathrm{CaO}-\mathrm{MgO}-\mathrm{Al}_{2} \mathrm{O}_{3}-\mathrm{SiO}_{2}-\mathrm{H}_{2} \mathrm{O}-\mathrm{CO}_{2}\right)$, a partir de um protolito harzburgítico.

LITOGEOQUÍMICA Para melhor se conhecer a evolução petrológica e tectônica dos metaultramafitos da Fazenda da Roseta e do Morro do Corisco realizaram-se análises litogeoquímicas incluindo elementos maiores, traços e elementos terras raras (ETR) de 6 (seis) amostras selecionadas como os litotipos mais diversos, menos alterados e mais representativos (Tab. 1), assim como também foram utilizados 3 análises químicas executadas no serpentinito da Fazenda da Roseta por Almeida (1998). Através do uso de diferentes diagramas petrotectônicos representativos para rochas ultramáficas, estes mostram que os corpos estudados se

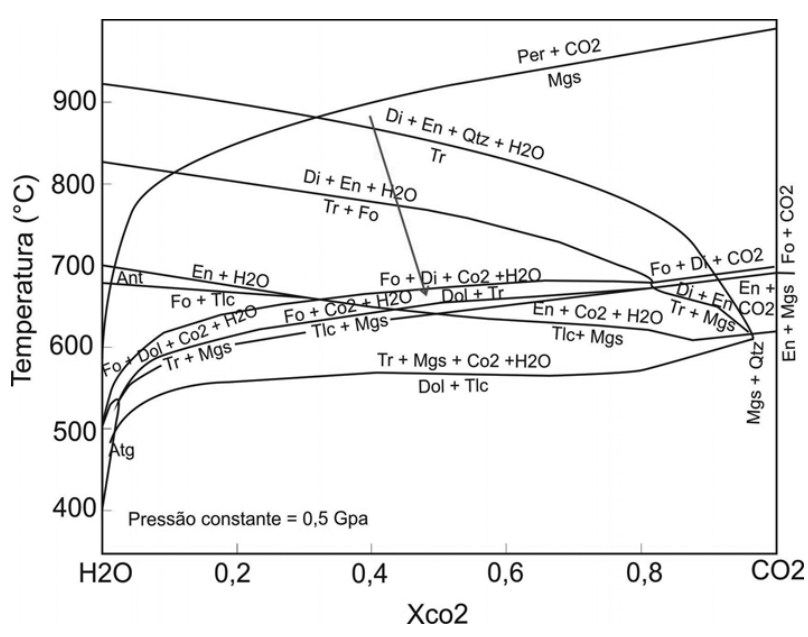

Figura 6 - Diagrama simplificado de fases para o sistema $\mathrm{CaO}-\mathrm{MgO}-\mathrm{SiO}_{2}-\mathrm{H}_{2} \mathrm{O}-\mathrm{CO}_{2}$ a $0.5 \mathrm{GPa}$ que apresenta a variação de fases minerais em função das condições de temperatura e concentração de $\mathrm{CO}_{2}$ (T-X $\mathrm{CO}_{2}$; extraido e modificado de Winter 2001). A seta vermelha indica a provável evolução retrometamórfica, após o píco metamórfico dos meta-serpentinitos da Fazenda Roseta.

posicionam, na maioria, em campos de peridotitos ofiolíticos e peridotitos abissais serpentinizados (Fig. 9).

Na figura 8-A, nos diagramas A (Niu 2004), B e C (Boudinier \& Godard 2004), D (Gülaçar \& Delaloye 1976) e E e F (Coleman 1977), os meta-serpentinitos da Fazenda da Roseta e do Morro do Corisco posicionam-se, invariavelmente, nos campos de dunitos, peridotitos, abissais ou ofiolíticos, serpentinizados ou não, associados a complexos alpinos ou ofiolíticos sugerindo sua provável herança de meta-ultramafitos gerados em ambiente oceânico. De um modo geral, estes metaserpentinitos, normalizados ao manto primitivo (Fig. 9; Jagoutz et al. 1979) apresentam um enriquecimento em elementos litófilos ( $\mathrm{U}, \mathrm{Ba}, \mathrm{Rb}, \mathrm{Sr}$ e $\mathrm{Pb}$ ) e tem valores próximos a 1 para elementos siderófilos $(\mathrm{Ni}, \mathrm{Cr}$ e $\mathrm{V}$; Fig. 9). Os dados normalizados e os teores absolutos destes meta-serpentinitos sugerem uma natureza primária similar a de rochas ultramáficas de origem oceânica e que estiveram sujeitas a processos de serpentinização e/ou metamorfismo regional progressivo e/ou regressivo. Ainda, uma característica geral e notável são as anomalias positivas de $\mathrm{Ba}, \mathrm{Th}, \mathrm{U}, \mathrm{Hf}, \mathrm{Ta}, \mathrm{Pb}, \mathrm{Zn}, \mathrm{La}$ e Eu nestas rochas, que tem de ser atribuída a processos hidrotermais (de fundo oceânico?) com interação de fluídos (água do mar? e/ou metamórficos) ricos nestes elementos litófilos, incluindo alguns HFSE ("high field strength elements"), com os ultramafitos (originalmente muito pobres nos acima citados elementos devido as suas baixas densidades de carga e porque eles são dificilmente acomodados pelos principais minerais do manto; e.g., Goldschmidt 1954, Albaréde 2003).

Apesar destes meta-serpentinitos apresentarem assinaturas por vezes muito similares, algumas discre- 

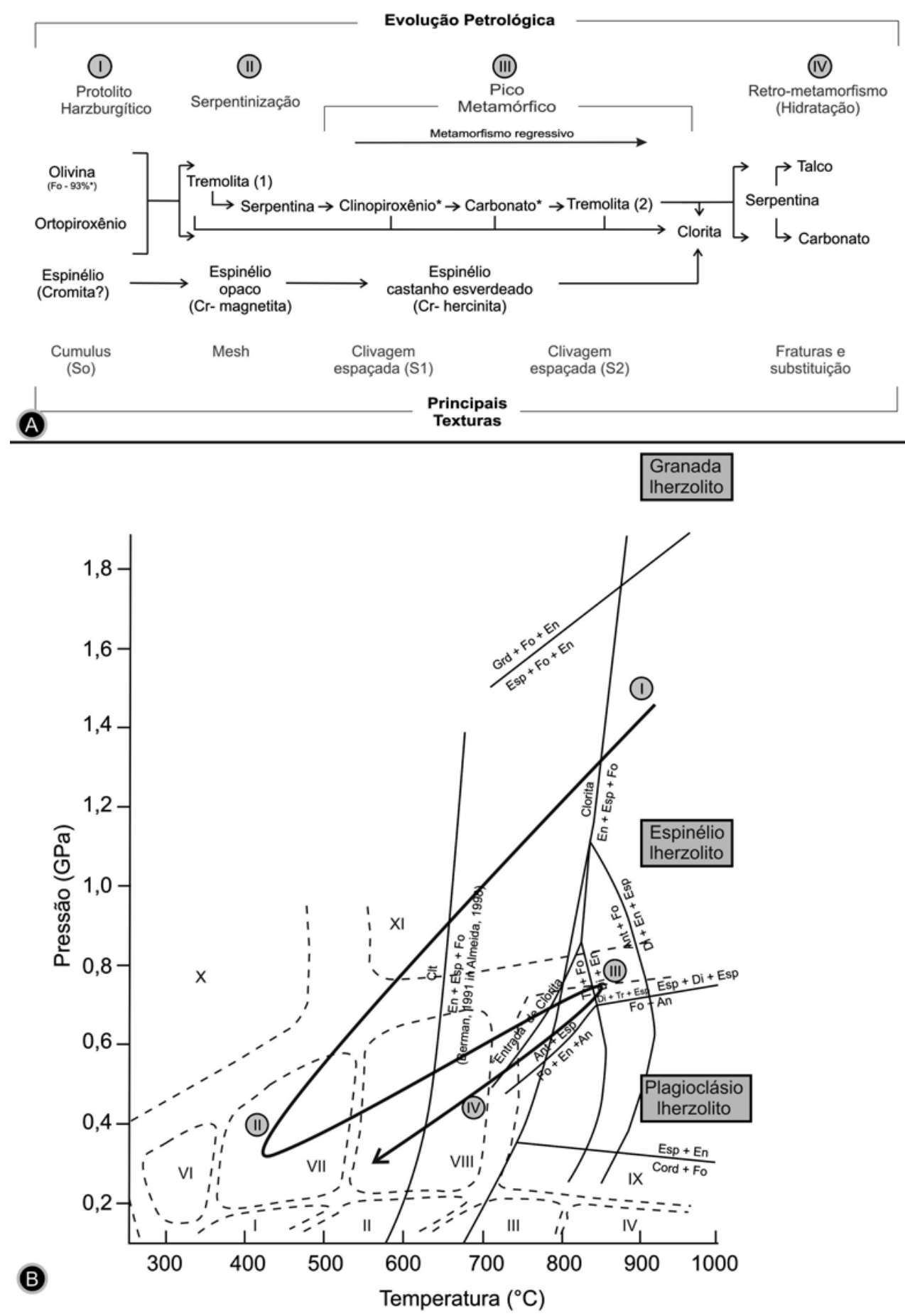

Figura 7 - Diagrama de pressão e temperatura que mostra a evolução petrológica dos meta-serpentinitos da Fazenda da Roseta e do Morro do Corisco com a trajetória P-T sugerida (seta) a partir de diagramas de fases do sistema MASH e CMASH. Estes dados estão sobrepostos aos campos de condições metamórficas das fácies: I) albita-epidoto hornfels; II) hornblenda hornfels; III) piroxênio hornfels; IV) sanidinito; V) zeólita; VI) prehnita-pumpellyita;VII) xisto verde; VIII) anfibolito; $I X)$ granulito X) xisto azul; e, XI) eclogito (extraído e modificado de Yardley 1996).

pâncias litogeoquímicas são observadas entre os serpentinitos da Fazenda da Roseta e do Morro do Corisco, especialmente nas concentrações de $\mathrm{Ba}$ e $\mathrm{Sr}$. O Ba ocorre em mais altas concentrações relativas nos metaserpentinitos do Morro do Corisco e o Sr na Fazenda da Roseta. Altas concentrações de $\mathrm{Sr}$ em serpentinitos 
Tabela 1 - Tabela dos resultados litogeoquímicos para os serpentinitos do Morro do Corisco e da Fazenda da Roseta (análises realizadas no Laboratório ACME Ltd. Canadá).

\begin{tabular}{|c|c|c|c|c|c|c|c|c|c|c|c|c|c|}
\hline ULTRAMAFITO & $\begin{array}{c}\mathrm{SiO} 2 \\
(\%)\end{array}$ & $\begin{array}{c}\mathrm{A} 12 \mathrm{O} 3 \\
(\%)\end{array}$ & $\begin{array}{c}\mathrm{Fe} 2 \mathrm{O} 3 \\
(\%)\end{array}$ & $\begin{array}{c}\mathrm{MgO} \\
(\%)\end{array}$ & $\begin{array}{l}\mathrm{CaO} \\
(\%)\end{array}$ & $\begin{array}{c}\mathrm{Na} 2 \mathrm{O} \\
(\%)\end{array}$ & $\begin{array}{c}\mathrm{K} 2 \mathrm{O} \\
(\%)\end{array}$ & $\begin{array}{c}\mathrm{TiO} 2 \\
(\%)\end{array}$ & $\begin{array}{c}\mathrm{P} 2 \mathrm{O} 5 \\
(\%)\end{array}$ & $\begin{array}{c}\mathrm{MnO} \\
(\%)\end{array}$ & $\begin{array}{c}\mathrm{Cr} 2 \mathrm{O} 3 \\
(\%)\end{array}$ & $\begin{array}{c}\mathrm{Ni} \\
(\mathrm{ppm})\end{array}$ & $\begin{array}{c}\mathrm{Cr} \\
(\mathrm{ppm})\end{array}$ \\
\hline CORISCO & 39,00 & 0,75 & 8,57 & 34,69 & 0,04 & 0,01 & 0,04 & 0,01 & 0,01 & 0,08 & 0,39 & 4450,00 & 0,27 \\
\hline CORISCO & 38,36 & 1,23 & 7,16 & 36,53 & 0,38 & 0,03 & 0,04 & 0,01 & 0,01 & 0,10 & 0,40 & 2292,00 & 0,27 \\
\hline CORISCO & 42,10 & 0,45 & 8,15 & 33,51 & 0,01 & 0,01 & 0,04 & 0,03 & 0,02 & 0,09 & 0,40 & 2139,00 & 0,28 \\
\hline CORISCO & 40,47 & 0,99 & 7,30 & 36,21 & 0,37 & 0,01 & 0,04 & 0,03 & 0,01 & 0,10 & 0,37 & 2061,00 & 0,25 \\
\hline CORISCO & 39,91 & 0,90 & 5,79 & 36,59 & 1,30 & 0,01 & 0,04 & 0,02 & 0,01 & 0,09 & 0,26 & 1940,00 & 0,18 \\
\hline ROSETA & 36,52 & 0,67 & 6,81 & 37,01 & 1,88 & 0,01 & 0,04 & 0,01 & 0,01 & 0,09 & 0,31 & 2285,00 & 0,21 \\
\hline ULTRAMAFITO & $\begin{array}{l}\text { LOI } \\
(\%)\end{array}$ & $\begin{array}{c}\text { TOT/C } \\
(\%)\end{array}$ & $\begin{array}{c}\mathrm{TOT} / \mathrm{S} \\
(\%)\end{array}$ & $\begin{array}{c}\text { SUM } \\
(\%)\end{array}$ & $\begin{array}{c}\mathrm{Ba} \\
(\mathrm{ppm})\end{array}$ & $\begin{array}{c}\mathrm{Be} \\
(\mathrm{ppm})\end{array}$ & $\begin{array}{c}\mathrm{Co} \\
\text { (ppm) }\end{array}$ & $\begin{array}{c}\mathrm{Cs} \\
(\mathrm{ppm})\end{array}$ & $\begin{array}{c}\mathrm{Ga} \\
(\mathrm{ppm})\end{array}$ & $\begin{array}{c}\mathrm{Hf} \\
(\mathrm{ppm})\end{array}$ & $\begin{array}{c}\mathrm{Sc} \\
(\mathrm{ppm})\end{array}$ & $\begin{array}{c}\mathrm{Rb} \\
(\mathrm{ppm})\end{array}$ & $\begin{array}{c}\mathrm{Sr} \\
(\mathrm{ppm})\end{array}$ \\
\hline CORISCO & 15,80 & 0,06 & 0,01 & 99,90 & 33,00 & 1,00 & 128,60 & 0,40 & 0,60 & 0,50 & 7,00 & 0,70 & 2,10 \\
\hline CORISCO & 15,40 & 0,20 & 0,01 & 99,91 & 8,20 & 1,00 & 99,80 & 0,10 & 1,40 & 0,50 & 8,00 & 0,50 & 4,90 \\
\hline CORISCO & 15,00 & 0,06 & 0,01 & 100,03 & 55,50 & 1,00 & 117,80 & 0,40 & 0,50 & 0,50 & 5,00 & 0,50 & 1,60 \\
\hline CORISCO & 13,80 & 0,06 & 0,01 & 99,91 & 31,00 & 1,00 & 93,70 & 0,30 & 0,50 & 0,50 & 6,00 & 0,50 & 2,50 \\
\hline CORISCO & 14,80 & 0,45 & 0,01 & 99,91 & 21,70 & 1,00 & 94,30 & 0,10 & 0,50 & 0,50 & 6,00 & 0,50 & 4,20 \\
\hline ROSETA & 16,30 & 1,07 & 0,01 & 99,92 & 2,40 & 1,00 & 109,30 & 0,10 & 0,50 & 0,50 & 5,00 & 0,50 & 17,10 \\
\hline ULTRAMAFITO & $\begin{array}{c}\mathrm{V} \\
(\mathrm{ppm})\end{array}$ & $\begin{array}{c}\mathrm{Zr} \\
(\mathrm{ppm})\end{array}$ & $\begin{array}{c}\mathrm{Cu} \\
(\mathrm{ppm})\end{array}$ & $\begin{array}{c}\mathrm{Zn} \\
(\mathrm{ppm})\end{array}$ & $\begin{array}{c}\mathrm{La} \\
(\mathrm{ppm})\end{array}$ & $\begin{array}{c}\mathrm{Ce} \\
(\mathrm{ppm})\end{array}$ & $\begin{array}{c}\mathrm{Pr} \\
(\mathrm{ppm})\end{array}$ & $\begin{array}{c}\mathrm{Nd} \\
(\mathrm{ppm})\end{array}$ & $\begin{array}{c}\mathrm{Sm} \\
(\mathrm{ppm})\end{array}$ & $\begin{array}{c}\mathrm{Eu} \\
(\mathrm{ppm})\end{array}$ & $\begin{array}{c}\mathrm{Gd} \\
(\mathrm{ppm})\end{array}$ & $\begin{array}{c}\mathrm{Tb} \\
(\mathrm{ppm})\end{array}$ & $\begin{array}{c}\text { Dy } \\
\text { (ppm) }\end{array}$ \\
\hline CORISCO & 26,00 & 0,50 & 7,40 & 25,00 & 0,50 & 0,50 & 0,05 & 0,40 & 0,10 & 0,05 & 0,05 & 0,01 & 0,05 \\
\hline CORISCO & 28,00 & 2,10 & 4,10 & 17,00 & 0,50 & 0,50 & 0,02 & 0,40 & 0,10 & 0,05 & 0,07 & 0,01 & 0,05 \\
\hline CORISCO & 21,00 & 0,50 & 2,70 & 28,00 & 0,50 & 0,50 & 0,02 & 0,40 & 0,10 & 0,05 & 0,05 & 0,01 & 0,05 \\
\hline CORISCO & 33,00 & 0,60 & 5,20 & 14,00 & 0,50 & 0,50 & 0,04 & 0,40 & 0,10 & 0,05 & 0,05 & 0,02 & 0,05 \\
\hline CORISCO & 29,00 & 0,50 & 3,60 & 12,00 & 0,50 & 0,50 & 0,02 & 0,40 & 0,10 & 0,05 & 0,07 & 0,01 & 0,07 \\
\hline ROSETA & 27,00 & 0,50 & 5,80 & 26,00 & 0,50 & 0,50 & 0,02 & 0,40 & 0,10 & 0,05 & 0,05 & 0,02 & 0,05 \\
\hline ULTRAMAFITO & $\begin{array}{c}\text { Ho } \\
\text { (ppm) }\end{array}$ & $\begin{array}{c}\mathrm{Er} \\
(\mathrm{ppm})\end{array}$ & $\begin{array}{c}\mathrm{Tm} \\
(\mathrm{ppm})\end{array}$ & $\begin{array}{c}\mathrm{Yb} \\
(\mathrm{ppm})\end{array}$ & $\begin{array}{c}\mathrm{Lu} \\
(\mathrm{ppm})\end{array}$ & $\begin{array}{c}\mathrm{Y} \\
(\mathrm{ppm})\end{array}$ & & & & & & & \\
\hline CORISCO & 0,05 & 0,05 & 0,05 & 0,05 & 0,01 & 0,40 & & & & & & & \\
\hline CORISCO & 0,05 & 0,05 & 0,05 & 0,06 & 0,01 & 0,40 & & & & & & & \\
\hline CORISCO & 0,05 & 0,05 & 0,05 & 0,06 & 0,01 & 0,20 & & & & & & & \\
\hline CORISCO & 0,05 & 0,05 & 0,05 & 0,05 & 0,01 & 0,30 & & & & & & & \\
\hline CORISCO & 0,05 & 0,05 & 0,05 & 0,05 & 0,01 & 0,30 & & & & & & & \\
\hline
\end{tabular}

oceânicos da zona da calcita foram reportadas por Gibson et al. (1996), que apresentaram valores na ordem de até 10 ppm e relacionaram a abundância de Ba diretamente com a quantidade modal de carbonato (calcita). De modo similar, em comparação com os metaserpentinitos deste estudo isto pode evidenciar, assim, uma natureza similar para estas anomalias de $\mathrm{Ba}$. De acordo com estes dados, as discrepantes concentrações, relativas e absolutas, de $\mathrm{Sr}$ nos meta-serpentinitos da
Fazenda da Roseta, em relação as do Morro do Coriso, estão provavelmente relacionadas a grande quantidade modal de carbonato encontrada nestes litotipos e que foram, provavelmente, adicionadas nos processos hidrotermais e/ou metamórficos superimpostos.

DISCUSSÃO Nos meta-serpentinitos da Fazenda da Roseta e do Morro do Corisco, foram texturalmente reconhecidas reestruturação da mineralogia e das texturas 

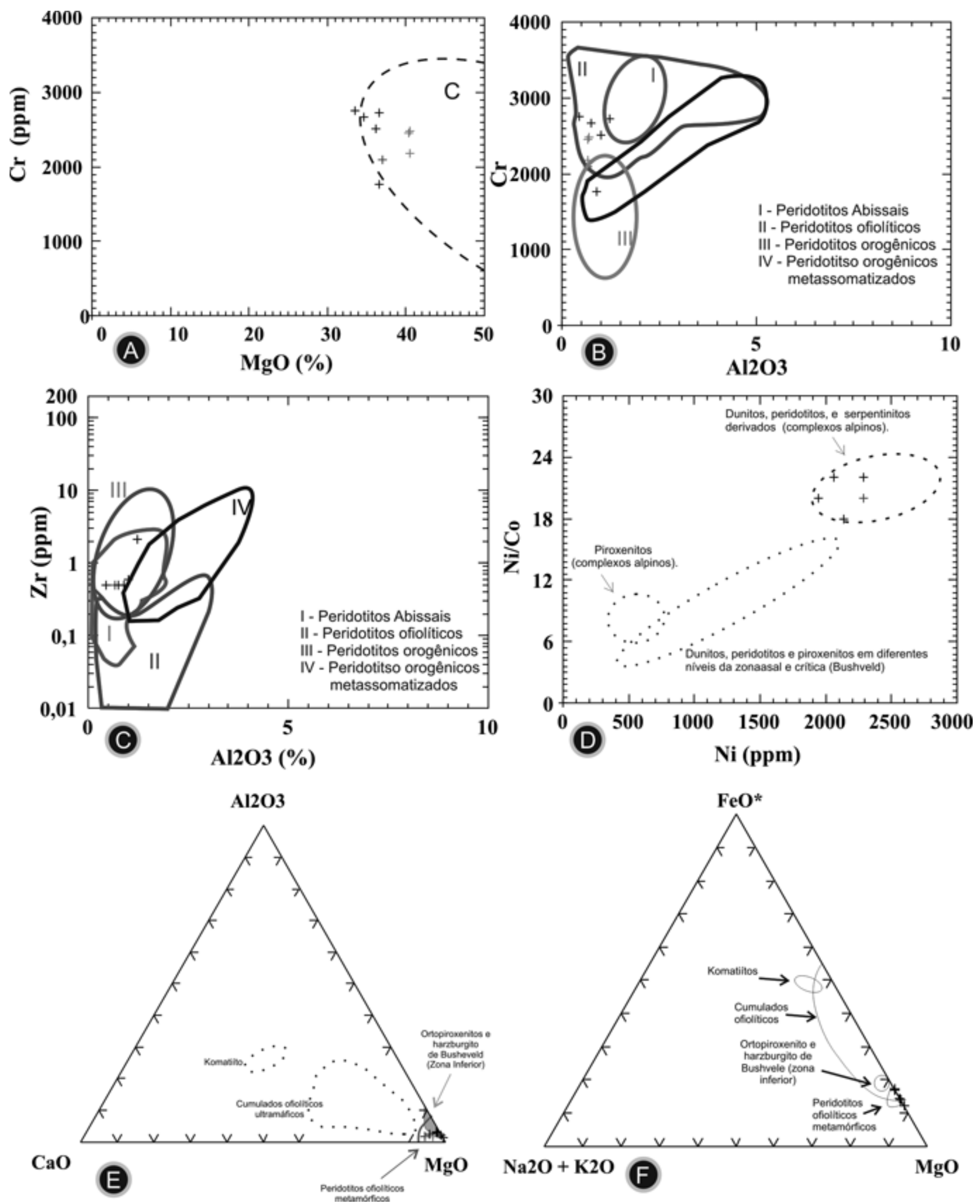

Figura 8 - Diagramas binários que contém amostras deste trabalho e que mostram relações para vários campos de peridotitos: A) $\mathrm{Cr} X \mathrm{MgO}$ (extraído de Niu 2004); $\mathrm{B}$ ) $\mathrm{Cr} \mathrm{X} \mathrm{Al}_{2} \mathrm{O}_{3}$ (extraído de Bodinier \& Godard 2004); C) $\mathrm{Zr} \mathrm{X} \mathrm{Al} \mathrm{O}_{3}$ (extraído de Boudinier \& Godard 2004); D) relação de Ni/Co X Ni (extraído de Gülaçar \& Delaloye 1976); e diagramas ternários (Coleman 1977) que apresentam a relação de: E) $\mathrm{Al}_{2} \mathrm{O}_{3}$ $X \mathrm{CaO} X \mathrm{MgO}$; F) $\mathrm{Na}_{2} \mathrm{O}+\mathrm{K}_{2} \mathrm{O} X \mathrm{MgO} X \mathrm{FeO}^{*}$. $\mathrm{FeO}$ * é apresentado como Fe total. Cruzes escuras: serpentinitos do Morro do Corisco; cruzes claras: serpentinito da Fazenda da Roseta. 


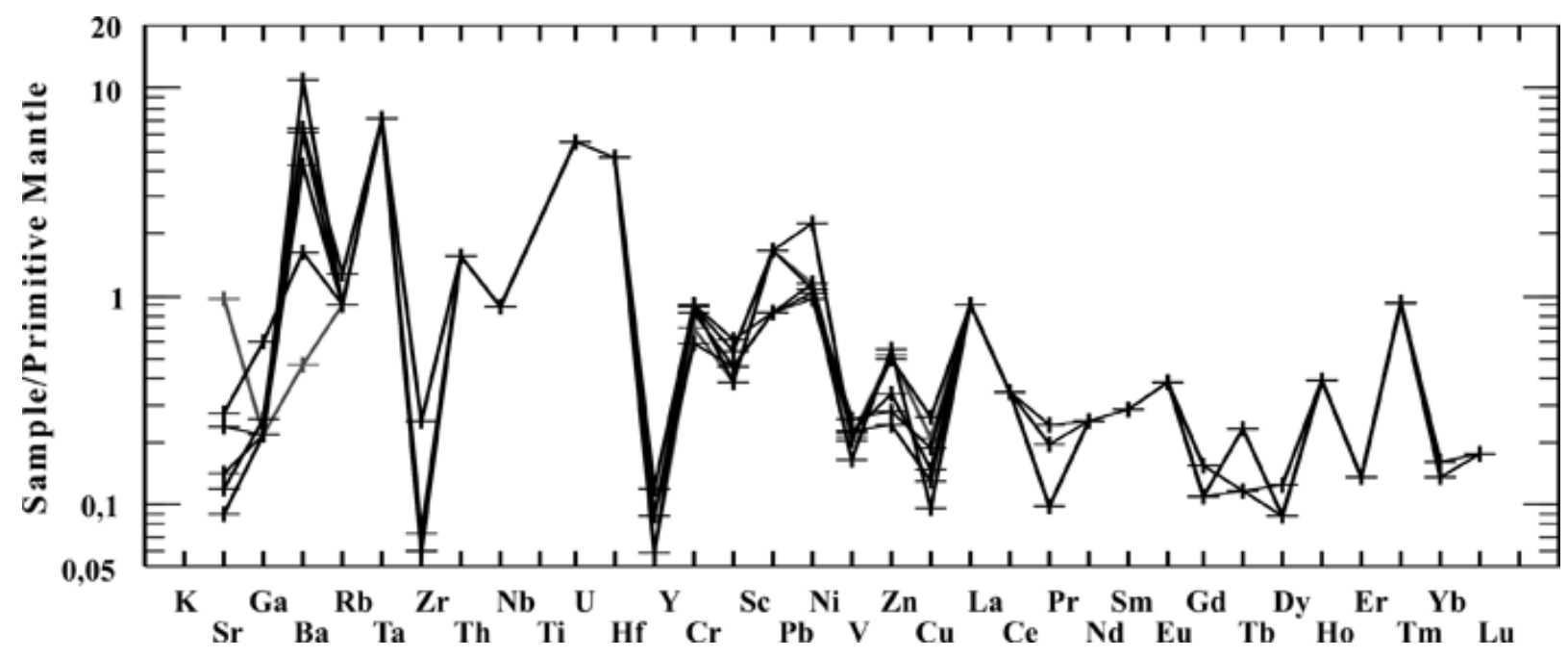

Figura 9 - "Spidergrams" de elementos traços e Terras Raras (ETR) de meta-serpentinitos do Morro do Corisco e da Fazenda da Roseta normalizados para valores do manto primitivo (Jagoutz et al. 1979).

(como as evidências texturais para os meta-serpentinitos da Fazenda da Roseta que sugerem uma gênese do clinopiroxênio (cpx) às custas de serpentina e subsidiam a formação de carbonato, em equilíbrio com cpx e, posteriormente, a neoformação de clinoanfibólio (tremolita II), a partir de rochas primárias plutônicas cumuláticas, essencialmente de composição harzburgítica. Estes dados indicam condições de cristalização e fracionamento magmático em condições de elevada pressão, com valores acima de $10 \mathrm{Kbar}$ (limite máximo de estabilidade do plagioclásio; e.g. Green \& Hibberson 1970, Green \& Ringwood 1970), as quais estão associadas a profundidades superiores a $35 \mathrm{Km}$ o que, em ambientes continentais corresponde a porções inferiores da crosta ou sub-crustais e, em ambientes oceânicos, estas condições atingiriam níveis mantélicos (Best 1982).

A caracterização da serpentina, através de análises de diframetria de raios-X, identificou clinocrisotila e lizardita como as variedades de serpentina existentes nestes serpentinitos. Trommsdorff \& Evans (1974) apresentaram valores da ordem de 100 a $300^{\circ} \mathrm{C}$ como as temperaturas favoráveis para a formação da paragênese lizardita +clinocrisotila em ambiente oceânico, com valores superiores a $300^{\circ} \mathrm{C}$ para associações com antigorita, resultante de metamorfismo regional. Coleman (1977), atribui a associação de lizardita +clinocrisotila +brucita +espinélio (magnetita) como sendo a associação típica de serpentinitos desenvolvidos a partir de peridotitos ofiolíticos em ambientes oceânicos e considerou que peridotitos serpentinizados em metamorfismo regional de médio a alto grau possuem, principalmente, antigorita como a serpentina estável.

Diante destes corpos ultramáficos localizarem-se em meio a metassedimentos de alto grau metamórfico, de origem oceânica, apresentarem formatos ovóides, com pequenas dimensões, estarem alinhadas na direção da xistosidade principal regional, apresentarem as mesmas deformações de suas rochas circundantes e estarem posicionadas ao longo de falhas de empurrões profundas, estarem associadas a ocorrências de retro-eclogitos, contemporâneas à estruturação da Faixa Brasília Sul (Paciullo et al. 2003), provavelmente, representam fragmentos remanescentes da zona de transição da seção crustal a sub-crustal oceânica. Estes ultramafitos foram, provavelmente incorporados tectonicamente na crosta continental, compondo associações do tipo alpinas, orogênicas ou, mesmo, ofiolíticas, e que foram geradas no campo de estabilidade dos espinélio peridotitos, podendo ser incluídos no grupos dos peridotitos orogênicos de pressão intermediária (IP; Boudinier \& Godard 2004).

O carater alóctone destes corpos já foi mencionado por diversos autores (e.g., Vilas 1960, Santos 1972 e Magalhães 1985), e interpretações semelhantes foram feitas por Berbert (1981) ao designar o ultramafito do Morro do Corisco como do "tipo alpino" relacionado a sequências ofiolíticas. Ainda, autores como Ribeiro (1995 e 1997), Paciullo et al. (2003), Heilbron et al. (2003) e Ribeiro et al. (2003), relacionaram os (meta) ultramafitos posicionados nas unidades das megassequências sedimentares da região, como representantes do manto litosférico, relacionados a ofiolitos, ou não. Por fim, Roigh \& Schrank (1992) em estudos de (meta) ultramafitos na região de Jacuí-Nova Resende (Sul de MG), próxima a região deste trabalho, ainda na Faixa Brasília Sul, atribuiram a corpos semelhantes, localizados ao longo de falhas de empurrão, que esses seriam possíveis fragmentos ofiolíticos, posicionados em uma sutura de idade brasiliana, em evento de colisão continente-continente, com vergência para leste.

Estudos executados em anfibolitos e retroeclogito máfico, localizados no domínio III, região de São Vicente de Minas (MG) (Gonçalves \& Figueiredo 1992), indicaram protólitos basálticos toleíticos, com predominância de basaltos continentais associados ao embasamento e do tipo MORB nas unidades metassedimentares. Estes últimos foram sugeridos como pos- 
síveis fragmentos de unidades de sequência ofiolítica, desmembrada na Orogênese Brasiliana (Gonçalves \& Figueiredo 1992, Paciullo 1992 e 1997).

Por outro lado, Almeida (1992 e 1998), porém, atribuiu a esses corpos ultramáficos, como sendo complexos acamadados intracratônicos formados por processos de cristalização fracionada e diferenciação de magmas toleíticos, intrudidos ao longo da evolução das bacias proterozóicas. No entanto, além dos dados acima citados e discutidos, a discrepância de grau metamórfico observada entre alguns (meta)ultramafitos e suas rochas circundantes, principalmente, nos meta-harzburgitos cumuláticos da região entre Andrelândia e Arantina e da Serra da Garça (Mhc-An-Ar e SG, Pinheiro 2008), que registram fácies granulito de alta pressão, em meio aos metassedimentos oceânicos metamorfisados em fácies anfibolito, evidencia uma trajetória metamórfico-deformacional não uniforme entre os mesmos. Caso o posicionamento dos (meta)ultramafitos tivesse ocorrido em evento magmático intrusivo relacionado a abertura da bacia, os registros metamórfico-deformacionais impressos seriam de mesma intensidade. Outro fator não favorável a natureza intrusiva destes (meta)ultramafitos é a ocorrência destes corpos ao longo de falhas de empurrão profundas associadas a retro-granulitos e retro-eclogitos máficos, sem evidências de processos metamórficos semelhantes nos metassedimentos circundantes (Pinheiro 2008, inédito), o que sugere, desta forma, a colocação destes corpos em profundidades superiores aquelas a que os metassedimentos circundantes foram submetidos.

Por fim, um fator significante ao posicionamento a frio destes corpos é a presença de litologias retrometamorfisadas ou re-equilibradas para o grau metamórfico das rochas circundantes, que configuram auréolas metamórficas, muito comuns na base de ofiolitos posicionados tectonicamente (e.g., Omã, Bay of Island e Semail). Estas litologias, diagnosticadas na região do Morro do Corisco e da Fazenda da Roseta, ou seja, nos corpos de maiores magnitudes, ocorrem comumente na borda de contato dos ultramafitos com as rochas circundantes e apresentam um registro de maior grau metamórfico em relação ao seu núcleo mais preservado.

CONCLUSÕES Os (meta)serpentinitos do Morro do Corisco e da Fazenda da Roseta, através de análises petrográficas, petroquímicas e petrológicas, apresentaram uma relação genética entre si, a partir de uma diferenciação de um magma comum. O modo de ocorrência destas rochas, encaixadas em metassedimentos oceânicos, de alto grau, associados a falhas profundas de empurrão, que envolvem granulitos, eclogitos e lentes do embasamento, e a similaridade com unidades de sequências de complexos ofiolíticos ou corpos alpinos, sugeriram para estes corpos um posicionamento, a partir de diferentes níveis crustais-subcrustais de natureza oceânica, formação em condições de pressão superiores a $10 \mathrm{Kbar}$, contemporâneas à arquiteturação do Gondwana Ocidental. Este processo ocorreu, provavelmente, no episódio de colisão dos continentes Rio de La Plata e São Francisco-Congo, e culminou no processo de fechamento do Oceano Brasilíades. Assim, estes corpos ultramáficos, representam fragmentos remanescentes de seções transicionais desta crosta oceânica, que foram exumados e posicionados em crosta continental, através de processo de obducção e transporte ao longo de falhas de empurrão profundas.

Os registros petrológicos evidenciaram uma evolução, essencialmente, em 4 episódios metamórfico-deformacionais principais:

1) formação da rocha protólito, ultramáfica cumulática, em provável ambiente crustal-subcrustal oceânico;

2) processo de despressurização, com re-equilíbrio, de fácies zeólita a anfibolito, relacionado a hidrotermalismo e/ou metamorfismo de fundo oceânico;

3) metamorfismo de fácies anfibolito a granulito, possivelmente, associado ao processo de subducção relacionado ao fechamento do Oceano Brasilíades, em um provável cenário tectônico de margem convergente, que atingiu pico metamórfico em fácies granulito de alta pressão ou eclogito de ultra alta pressão, associado a estruturação da Orogênese Brasiliana, concomitantemente a formação das nappes estruturais, e que culminou na exumação dos ultramafitos; e,

4) um retrometamorfismo que atingiu o fácies xisto verde, como registro da Orogênese Ribeira.

Agradecimentos ÀFAPEMIG(processoCRA1058/04) pelo financiamento ao projeto que possibilitou o desenvolvimento de uma dissertação de mestrado (M.A.P. Pinheiro) \& ao Prof. RudolffA. Trow (UFRJ) que forneceu inúmeras informações de extrema valia e importância para o desenvolvimento deste trabalho. A CAPES/CNPq por uma bolsa de mestrado (M.A.P. Pinheiro).

\section{Referências}

Albarède F. 2003. Geochemistry - an introduction. Cambridge University Press, Cambridge, UK, 248p.

Almeida S. 1992. Petrografia e geoquímica de rochas ultramáficas na região de Liberdade e Carrancas, Minas Gerais. Dissertação de Mestrado, Inst. Geociências, Universidade Federal do Rio de Janeiro, Rio de Janeiro, $166 \mathrm{p}$.

Almeida S. 1998. Petrologia de rochas ultramáficas associadas ao Grupo Andrelândia e seu embasamento, na re- gião de Liberdade, Arantina, Andrelândia, São Vicente de Minas e Carrancas, MG. Tese de Doutoramento, Instituto de Geociências, Universidade de São Paulo, 194p.

Best M.G. 1982. Igneous and Metamorphic Petrology. Freeman \& Company Ed., 630p.

Bodinier J.L. \& Godard M. 2004. Orogenic, Ophiolitic, and Abyssal Peridotites, in The Mantle and Core. In: Carlson R.W. (ed.) Treatise on Geochemistry . Oxford, ElsevierPergamon, v. 2, p.103-170. 
Campos-Neto M.C. \& Caby R. 2000. Terrane Accretion And Upward Extrusion Of High-Pressure Granulites In The Neoproterozoic Nappes Of Southeast Brazil: Petrologic And Structural Constraints. Tectonics, 19(4):669-687.

Coleman R.G. 1977. Ophiolites - Ancient Oceanic Lithosphere? In: Wyllie P.J. (ed.) Minerals and Rocks. Berlin, Germany, Springer-Verlag, 12:74-117.

Evans B.W. \& Frost B.R. 1975. Chrome-spinel in progressive metamorphism - A preliminary analysis. Geochim. Cosmochim. Acta, 39:959-972.

Evans B.W. 1977. Metamorphism of alpine peridotite and serpentinite. Ann. Rev. Earth Planet. Sci., 5:397-447.

Evans B.W. \& Trommsdorf V. 1970. Regional metamorphism of ultramafic rocks in the Central Alps: parageneses in the system CaO-M8O-SiO2-H2O. Schweizerische Mineralo-gischeund Petrographische Mitteilungen, 50:481492.

Green D.H. \& Hibberson W. 1970. The instability of plagioclase in peridotite at high pressure. Lithos, 3:209-221.

Green D.H. \& Ringwood E.A. 1970. Mineralogy of peridotitic compositions under upper mantle conditions. Phys. Earth Planet. Int., 3:359-371.

Gibson I.L., Milliken K.L. \& Morgan J.K. 1996. Serpentinite-breccia landslide deposits generated during crustal extension at the Iberia margin. In: Whitmarsh R.B., Sawyer D.S., Klaus A., Masson D.G. (eds.) Proceeding o the ocean drilling program, Scientific Results. College Station, TX (Ocean Drilling Program), 149: 571-575. Disponível em: http://www-odp.tamu.edu/ publications/149_SR/chap_35/chap_35.htm.

Goldschmidt V.M. 1954. Geochemistry. London, Oxford University Press, 730p.

Gonçalves M.L. \& Figueiredo M.C.H. 1992. Geoquímica dos anfibolitos de Santana do Garambéu (MG): implicações sobre a evolução do Grupo Andrelândia. Geochimica Brasiliensis, 6:127-140.

Gülaçar O.F. \& DeLaloye M. 1976. Geochemistry of nickel, cobalt and copper in alpine type ultramafics rocks. Chemical Geology, 17:269-280.

Heilbron M., Duarte B.P., Valladares C.S., Nogueira J.R., Tupinambá M., Silva L.G.E. 2003. Síntese geológica regional do bloco oriental (Zona da Mata). In: Pedrosa Soares A.C., Noce C.M., Trouw R.A., Heilbron M. (eds). Projeto Sul de Minas. Belo Horizonte, UFMG, 8, 50p.

Jagoutz E., Palme H., Blum H., Cendales M., Dreibus G., Spettel B., Lorenz V., W€anke H. (1979). The abundances of major, minor and trace elements in the Earth's mantle as derived from primitive ultramafic nodules. Proceeding of 10th Lunar Planetary Science Conference. Geochimica et Cosmochimica Acta, 10(Supplement):2031-2051.

Magalhães A.C. 1985. Geologia de Corpos Ultramáficos da Região Compreendida entre São João Del Rey e Liberdade, com Ênfase Especial na Área de Carrancas, $M G$. Dissertação de Mestrado, Universidade Federal do Rio de Janeiro, Rio de Janeiro, 177p.

Niu Y. 2004. Bulk-rock major and trace element compositions of abyssal peridotites: Implications for mantle melting, melt extraction and post-melting processes be- neath mid-ocean ridges. J. Petrol., 45:2423-2458.

O’Hara M.J. 1967. Mineral parageneses in ultrabasic rocks. In: Wylie P.J. (ed.) Ultamafc and Related Rocks. New York, John Wiley and Sons Inc., p. 393-401.

Paciullo F.V.P., Ribeiro A., Trouw R.A.J. 2003. Geologia da Folha Andrelândia 1: 100.000. In: Pedrosa Soares A.C., Noce C.M., Trouw R.A.J., Heilbron M.. (org.) Geologia e recursos minerais do sudeste mineiro. Projeto Sul de Minas- Etapa I (COMIG, UFMG, UFRJ, UERJ), Relatório Final, 1ํㅗㄹ ed., Belo Horizonte, Companhia Mineradora de Minas Gerais - COMIG, v. I, p. 84-119.

Pinheiro M.A.P. 2008. Geologia e petrologia de rochas ultramáficas ofiolíticas neoproterozóicas de alto grau da Folha Andrelândia, porção sul do Cráton São Francisco, Minas Gerais. Dissertação Mestrado, Departamento de Geologia, UFOP, 168p.

Ribeiro A., Paciullo F.V.P., Andreis R.R., Trouw R.A.J., Heilbron M. 1990. Evolução policíclica proterozóica no sul do Cráton do São Francisco: análise da região de São João Del Rei e Andrelândia, MG. In: SBG, Congr. Bras. Geol., 36, Natal, Anais, 6:2605-2614.

Ribeiro A., Andreis R.R., Trouw R.A.J., Paciullo F.V.P., Valença J.G. 1995. Evolução das bacias proterozóicas e o termo-tectonismo brasiliano na margem sul do cráton do São Francisco. Rev. Bras. Geociências, 25(4):235-248.

Ribeiro A. 1997. Estratigrafia e paleoambiente nas sucessões metassedimentares proterozóicas das serras do Lenheiro e São José, São João del rei, Minas Gerais. Tese de Doutoramento, Inst. de Geociências, Universidade Federal do Rio de Janeiro, 167p.

Roig H.L. \& Schrank A. 1992. Caracterização da zona de sutura Jacuí-Conceição da Aparecida - Limite norte do Complexo de Guaxupé - MG. Congr. Brasileiro de Geol., 37, São Paulo, Bol. Res. Exp., p.283-284.

Strieder A.J. 1992. Serpentinização e metassomatismo em rochas ultramá-ficas: discussão das características e recomendações para o tratamento geoquímico. Rev. Bras. Geoc., 22(3):329-337

Santos L.C.S. 1972. Evolução geoquímica e mineralógica de um solo niquelífero. Dissertação de Mestrado, UFRJ, $105 \mathrm{p}$.

Trouw R.A.J., Ribeiro A., Paciullo F.V.P. 1986. Contribuição à geologia de Folha Barbacena, 1:250.000. In: SBG, Congr. Bras. Geol., 34, Goiânia, Anais, 2:974-984.

Trouw R.A.J. \& Pankhrust R.J. 1993. Idades radiométricas ao sul do Cráton do São Francisco: região da Folha Barbacena, Minas Gerais. In: Simp. Cráton São Francisco, 2, Salvador, 1993, Anais, p.260-262.

Yardley B.D.W., Mackenzie W.S., Guilford C. 1990. Atlas of Metamorphic Rocks and their Textures. N.Y., Longman Scientific \& Technical, 120p.

Winter J.D. 2001. An Introduction to Igneous and Metamorphic Petrology. Prentice Hall, 697p.

Manuscrito ID 11616 Submetido em 30 de junho de 2008 Aceito em 18 de dezembro de 2008 Sistema eletrônico de submissão 